\title{
ANALISIS RESIKO KEGIATAN DI ATAS KAPAL DENGAN METODE HAZOP ANALYSIS DI KMP. ATHAYA
}

\author{
Junatul Puadah \\ Politeknik Pelayaran Surabaya \\ e-mail: junatulpuadah6@gmail.com \\ Sereati Hasugian \\ Politeknik Pelayaran Surabaya \\ e-mail: h.sereati@gmail.com \\ Dwi Haryanto \\ Politeknik Pelayaran Surabaya \\ e-mail: dwiharyanto75@gmail.com
}

\begin{abstract}
ABSTRAK
Penelitian ini bertujuan untuk mengetahui resiko kegiatan diatas kapal dengan metode hazop analysis. Serta mengetahui pencegahan yang dapat meminimalisir potensi bahaya pada saat melakukan pekerjaan diatas kapal sesuai dengan aturan yang berlaku. Pengambilan data diperoleh dari penyebaran angket kuesioner, hasil observasi terhadap anak buah kapal dan wawancara dengan Chief Officer. Objek penelitian ini dilaksanakan di kapal KMP. Athaya. Sedangkan metode penelitian yang digunakan adalah metode kualitatif. Berdasarkan hasil penelitian dan analisis data yang dilakukan penulis menunjukan masih adanya standar keselamatan kerja yang tidak diterapkan oleh anak buah kapal khususnya dalam hal penggunaan alat keselamatan diri pada saat melaksanakan kegiatan operasional kapal sehingga berpotensi menimbulkan-kecelakaan kerja. Penggunaan alat pelindung diri berpengaruh besar dalam kegiatan yang ada dikapal. Untuk itu, demi meningkatkan kualitas dan kelancaran saat bekerja awak kapal dituntut untuk mematuhi segala peraturan yang ditetapkan di kapal dan menerapkan pemakaian peralatan pelindung diri dengan baik, agar dapat meminimalisir terjadinya kecelakaan kerja dan memaksimalkan kinerja di atas kapal.
\end{abstract}

Kata kunci : Analisis resiko, Metode hazop analysis, Kegiatan di atas kapal, Penerapan safety equipment.

\begin{abstract}
This study aims to determine the risk of activities on board the ship with hazop analysis method. As well as knowing the prevention that can minimize the potential danger when doing work on the ship in accordance with the applicable rules. The data was obtained from the dissemination of questionnaire questionnaires, observations of the crew and interviews with the Chief Officer. The location of this study was conducted while the author was in the practice of sailing on a KMP ship. Athaya. Based on the results of research and analysis of data conducted by the author shows that there are still work safety standards that are not applied by the crew, especially in terms of the use of personal safety equipment when carrying out ship operational activities so as to potentially cause work accidents. The application of safety equipment has a big effect in existing activities on the ship. Therefore, in order to improve the quality and smoothness while working the crew is required to comply with all regulations set on board and apply the use of safety equipment properly, in order to minimize the occurrence of work accidents and maximize performance on board.
\end{abstract}

Keywords : Risk Analysis, Hazop Analysis, Activities On The Ship, Application Of Safety Equipment 


\section{Pendahuluan}

Keselamatan kerja merupakan salah satu faktor utama yang harus dipenuhi agar awak kapal dapat bekerja dengan aman dan mendapatkan hasil yang maksimal. Kecelakaan bukanlah suatu peristiwa tunggal, tetapi merupakan hasil dari serangkaian penyebab yang saling berkaitan yang disebabkan oleh kelemahan pimpinan, pekerja, prosedur kerja yang tidak memadai, serta tindakan para pekerja yang tidak aman sehingga berakibat pada turunnya tingkat produktivitas kerja. Peralatan pelindung diri merupakan elemen yang penting untuk semua aktivitas yang melibatkan manusia atau sebuah lokasi dengan aktivitas manusia di dalamnya. Peralatan pelindung diri merupakan perlindungan pertama jika terjadi sebuah kecelakaan atau keadaan darurat, sehingga dapat meminimalkan risiko yang ada. Berdasarkan aturan Internasional Code of Safe Working Practice for Merchant Seafarers 2015 edition - Amandment 2, December 20178.3 Regulation 10 bahwa pelaut harus mengenakan alat pelindung diri yang disediakan saat mereka melaksanakan tugas, dan mengikuti instruksi penggunaan yang tepat.

Penyebab dari kecelakaan didasari oleh beberapa faktor, yaitu faktor yang paling dominan adalah sebab langsung (direct cause) yaitu faktor yang diakibatkan oleh perbuatan manusia yang salah (unsafe human act), misalnya :

a. Tidak mengikuti standar operasional proedur yang ada

b. Kurang hati-hati dalam melaksanakan suatu pekerjaan

c. Tidak tahu menggunakan alat keselamatan

d. Tidak mampu melaksanakan suatu pekerjaan

Berdasarkan pengalaman saat praktek di KMP. Athaya ada beberapa anak buah kapal yang belum menggunakan Personal Protective Equipment sesuai prosedur yang telah ditetapkan, seperti pada kejadian saat melaksanakan kerja harian. Juru Mudi terkena serpihan karat pada saat melakukan chipping di deck, hal ini disebabkan karena Juru Mudi tersebut tidak menggunakan safety googles. Begitupun pada kejadian yang terjadi pada Kelasi, Pada saat melaksanakan pemasangan nozzle springkle, Kelasi tersebut tidak menggunakan safety shoes, sehingga kelasi tersebut terpeleset dan terjatuh pada saat menaiki steger. Tidak adanya kesadaran dan pemahaman dalam penggunaan alat-alat keselamatan bahwa alat itu bukan untuk keselamatan orang lain tetapi untuk keselamatan kita sendiri.

Berdasarkan data dikapal bahwa jumlah peralatan keselamatan kerja yang tersedia di KMP. ATHAYA sesuai dengan jumlah crew yang ada di atas kapal yang berjumlah 32 orang. Namun dalam bekerja sehari-hari biasanya crew sengaja untuk tidak memakai alat-alat keselamatan karena dianggap hanya merepotkan saja dan membuat pergerakan pada saat bekerja tidak bebas, padahal mereka tidak menyadari bahwa kecelakaan dapat terjadi dimana saja dan kapan pun yang dapat merenggut nyawa manusia atau membuat cacat seumur hidup. Dengan terjadinya kecelakan di bagian deck kapal, maka menandakan bahwa banyak anak buah kapal yang belum terbiasa menggunakan alat keselamatan yang benar saat bekerja.

Oleh karena itu untuk meningkatkan kedisiplinan crew di atas kapal dalam penggunaan alatalat keselamatan maka diharapkan kepada perwira di atas kapal agar selalu mengawasi dan mengontrol para pekerja yang sedang melakukan suatu pekerjaan serta menegur langsung kepada crew yang tidak menggunakan peralatan keselamatan kerja dan memberikan himbauan-himbauan tentang bahaya dan akibat-akibat yang akan terjadi.

Untuk mengurangi atau menghilangkan bahaya yang dapat menyebabkan kecelakaan di tempat kerja, maka diperlukan suatu manajemen resiko kegiatannya meliputi identifikasi bahaya, analisis potensi bahaya, penilaian resiko, pengendalian resiko, serta pemantauan dan evaluasi. Proses identifikasi dan analisis potensi bahaya dapat dilakukan dengan menggunakan metode hazard and operability study (hazop). Menurut Hendro Nurcahyono (2013), Hazop adalah standar teknik analisis bahaya yang di gunakan dalam persiapan penetapan keamanan dalam sistem baru atau modifikasi untuk suatu keberadaan potensi bahaya atau masalah operabilitasnya. Hasil tersebut digunakan sebagai dasar pertimbangan menentukan strategi pengendalian resiko dan mengurangi kecelakaan di kapal. Oleh karena itu, kejadian ini perlu adanya penelitian menggunakan metode hazop analysis untuk mengelompokan bahaya-bahaya yang mungkin terjadi sehingga bisa dilakukan penanganan yang lebih agar bisa menanggulangi keadaan berbahaya. 
Tujuan dari penelitian ini adalah untuk mengetahui resiko kegiatan diatas kapal dengan metode hazop analysis. Serta mengetahui pencegahan yang dapat meminimalisir potensi bahaya pada saat melakukan pekerjaan diatas kapal sesuai dengan aturan yang berlaku. Berikut prosedur atau aturan yang terapkan di atas kapal KMP. Athaya No. Dokumen JL-100-10 sebagai berikut:

Prosedur Keselamatan dan Kesehatan Kerja yang Ada diKMP. Athaya :

a. Pencegahan Kebakaran.

1) Merokok.

a) Merokok hanya diperbolehkan pada tempat yang disediakan.

b) Pastikan puntung rokok dan batang korek api telah mati saat dibuang ke asbak atau kotak sampah.

2) Perlengkapan listrik dan lain - lain.

a) Orang yang tidak berwenang tidak boleh menangani pekerjaan yang terkait dengan peralatan dan perlengkapan listrik.

b) Semua kejadian kerusakan listrik segera dilaporkan kepada ahli listrik atau mereka yang diberi wewenang untuk penanganan listrik.

c) Setiap saluran listrik tidak boleh dibebani melebihi kapasitasnya karena dapat menyebabkan kebakaran.

b. Alat Pelindung Diri (PPE- Personal Protective Equipment).

Setiap karyawan harus mempergunakan alat pelindung diri (APD) apabila melakukan kegiatan dan atau dilokasi yang berpotensi bahaya. Alat pelindung diri yang dapat digunakan, antara lain:

1) Safety Helmets fungsinya, Untuk melindungi kepala terhadap benturan dengan benda keras.

2) Ear Protectors fungsinya, Melindungi telinga jika bekerja dilingkungan yang memiliki tingkat kebisingan yang tinggi.

3) Safety googles fungsinya, Melindungi mata dari cahaya atau benda yang membahayakan mata.

4) Pelindung Pernafasan fungsinya, Untuk lingkungan yang memiliki resiko debu dan polusi yang tinggi.

5) Safety gloves fungsinya, Melindungi tangan dari panas, benda kasar atua bahan - bahan kimia berbahaya.

6) Safety shoes fungsinya, Melindungi kaki dari barang - barang berbahaya

7) Tali Pengikat fungsinya, Pengikat badan untuk pekerjaan di ketinggian.

8) Pakaian Pelindung fungsinya, untuk melindungi badan sebagian atau seluruh bagian badan dari bahaya, seperti minyak panas, air, dll.

\section{Metodologi Penelitian}

Penelitian ini menggunakan metode penelitian kualitatif dengan metode hazop analysis. Adapun tujuan penelitian dengan metode hazop analysis adalah untuk mengetahui analisis resiko kegiatan diatas kapal sehingga lebih memperkuat analisa penulis dalam membuat suatu kesimpulan. Dimana hasil penelitian diperoleh dari hasil perangkingan resiko yang terjadi diatas kapal, kemudian dipaparkan secara tertulis oleh penulis.

Penulis melakukan observasi di KMP. Athaya selama 11 bulan dimulai tanggal 16 September 2019 hingga tanggal 25 Agustus 2020. Penelitian ini dilaksanakan dengan langkah langkah seperti diuraikan sebagai berikut. Pertama, penulis melakukan observasi. Kedua, berdasarkan hasil observasi bahwa crew deck pada saat melaksanakan pekerjaan harian ditemukan adanya melanggar peraturan kerja seperti, tidak memakai alat keselamatan kerja. Ketiga, mengumpukan data dengan observasi langsung, wawancara dan kuesioner. Populasi yang dimaksud dalam penelitian ini adalah seluruh crew deck yang ada diatas KMP. Athaya yang berjumlah 17 orang. Keempat, langkah berikutnya adalah tahapan perangkingan resiko serta penanggulan resiko yang akan dirangkum dan dianalisis. 


\section{Hasil Dan Pembahasan}

Keselamatan dan keamanan kerja merupakan faktor penting dalam melaksanakan kegiatan berkerja. Menurut Simanjuntak (1994), keselamatan kerja adalah kondisi keselamatan yang bebas dari resiko kecelakaan dan kerusakan dimana kita bekerja yang mencakup tentang kondisi bangunan, kondisi mesin, peralatan keselamatan dan kondisi pekerja. Sehubungan dengan itu maka awak kapal mempunyai tugas dan tanggung jawab yang besar dalam mencegah kecelakaan yang dapat menyebabkan kerugian dan penderitaan bagi semua pihak mulai dari awak kapal itu sendiri sampai pada tingkat perusahaan yaitu melalui usaha keselamatan kerja yang baik. Penulis mencoba menggambarkan permasalahan yang pernah dialami sewaktu melaksanakan praktek laut yaitu, kurang adanya kedisiplinan pada awak kapal untuk menggunakan peralatan keselamatan sesuai SOP yang ada pada saat melakukan pekerjaan.

Penelitian ini dilaksanakan dengan observasi lapangan secara langsung dan membagikan kuesioner untuk memperoleh temuan potensi bahaya (hazard). Kuesioner disebar kepada $17 \mathrm{crew}$ deck yang ada di atas kapal. Penulis mengidentifikasi adanya potensi bahaya yang terjadi di atas kapal dengan begitu penulis dapat mengelompokan bahaya - bahaya yang terjadi di atas kapal dan mengurangi jatuh nya korban jiwa.

Untuk menunjukan penentuan nilai likelihood dan consequences dari masing-masing sumber potensi bahaya sebagai berikut:

1. Likelihood (L) adalah kemungkinan terjadinya kecelakaan ketika terpapar dengan bahaya.

Tabel 1. Kriteria Likelihood

\begin{tabular}{|c|l|l|l|}
\hline \multirow{2}{*}{ No } & \multirow{2}{*}{$\begin{array}{c}\text { Likelihood } \\
\text { (Level Kriteria) }\end{array}$} & \multicolumn{2}{|c|}{ Description } \\
\cline { 3 - 4 } & Jarang Terjadi & $\begin{array}{l}\text { Kualitatif } \\
\text { Dapat dipikirkan tetapi } \\
\text { tidak hanya saat } \\
\text { keadaan ekstrim }\end{array}$ & Kurang dari 1 kali dalam 1 tahun \\
\hline 2. & Kemungkinan Kecil & $\begin{array}{l}\text { Belum terjadi tetapi } \\
\text { bisa muncul/terjadi } \\
\text { pada suatu waktu }\end{array}$ & Terjadi 1 kali per 1 tahun \\
\hline 3. & Mungkin & $\begin{array}{l}\text { Seharusnya terjadi dan } \\
\text { mungkin telah } \\
\text { menjadi/muncul disini } \\
\text { atau ditempat lain }\end{array}$ & 1 kali per 1 tahun \\
\hline 4. & Kemungkinan Besar & $\begin{array}{l}\text { Dapat terjadi dengan } \\
\text { mudah, mungkin } \\
\text { muncul dalam keadaan } \\
\text { yang paling banyak } \\
\text { terjadi }\end{array}$ & $\begin{array}{l}\text { Lebih dari 1 kali per tahun } \\
\text { hingga 1 kali per bulan }\end{array}$ \\
\hline 5. & Hampir Pasti & $\begin{array}{l}\text { Sering terjadi, } \\
\text { diharapkan muncul } \\
\text { dalam keadaan yang } \\
\text { paling banyak terjadi }\end{array}$ & Lebih dari 1 kali per bulan \\
\hline
\end{tabular}

Sumber: http://journals.ums.ac.id/index.php/jiti/article/download/621/361.

Kriteria likelihood merupakan tabel yang menunjukan kemungkinan yang akan terjadi di atas kapal dengan kemungkinan tersebut kita bisa mengantisipasi resiko yang akan terjadi dengan tindakan - tindakan sesuai SOP.

2. Severity atau consequences (C) adalah tingkat yang menunjukkan keparahan cidera dan kehilangan hari kerja. 
Tabel 2. Kriteria Consequences

\begin{tabular}{|c|l|l|l|}
\hline No & \multirow{2}{*}{$\begin{array}{c}\text { Consequences/Severity } \\
\text { (Level Uraian) }\end{array}$} & \multicolumn{1}{|c|}{ Keparahan Cidera } & \multicolumn{1}{|c|}{ Hari Kerja } \\
\cline { 3 - 4 } & Tidak Signifikan & $\begin{array}{l}\text { Kejadian tidak } \\
\text { menimbulkan kerugian } \\
\text { atau cidera pada manusia }\end{array}$ & $\begin{array}{l}\text { Tidak menyebabkan } \\
\text { kehilangan hari kerja }\end{array}$ \\
\hline 2. & Kecil & $\begin{array}{l}\text { Menimbulkan cidera } \\
\text { ringan, kerugian kecil dan } \\
\text { tidak menimbulkan } \\
\text { dampak serius } \\
\text { terhadap kelangsungan }\end{array}$ & $\begin{array}{l}\text { Masih dapat bekerja pada } \\
\text { hari/shift yang sama }\end{array}$ \\
\hline 3. & Sedang & $\begin{array}{l}\text { Cedera berat dan dirawat } \\
\text { dirumah sakit, tidak } \\
\text { menimbulkan cacat tetap, } \\
\text { kerugian financial sedang }\end{array}$ & $\begin{array}{l}\text { Kehilangan hari kerja } \\
\text { dibawah 3 hari }\end{array}$ \\
\hline 4. & Berat & $\begin{array}{l}\text { Menimbulkan cidera parah } \\
\text { dan cacat tetap }\end{array}$ & $\begin{array}{l}\text { Kehilangan hari kerja 3 } \\
\text { hari atau lebih }\end{array}$ \\
\hline 5. & Bencana & $\begin{array}{l}\text { Mengakibatkan korban } \\
\text { meninggal dan kerugian } \\
\text { parah }\end{array}$ & $\begin{array}{l}\text { Kehilangan hari kerja } \\
\text { selamanya }\end{array}$ \\
\hline
\end{tabular}

Sumber: http://journals.ums.ac.id/index.php/jiti/article/download/621/361.

Kriteria consequences adalah tabel yang menunjukan resiko yang akan terjadi jika kita melakukan suatu kegiatan di atas kapal dengan tidak melakukan sesuai SOP yang ada.

Setelah menentukan nilai likelihood dan consequences dari masing - masing sumber hazard, langkah berikutnya adalah mengalikan nilai likelihood dan consequences sehingga akan diperoleh tingkat bahaya/ risk level pada risk matrix yang akan digunakan untuk melakukan perangkingan terhadap sumber hazard yang nantinya akan dilakukan rekomendasi perbaikan.

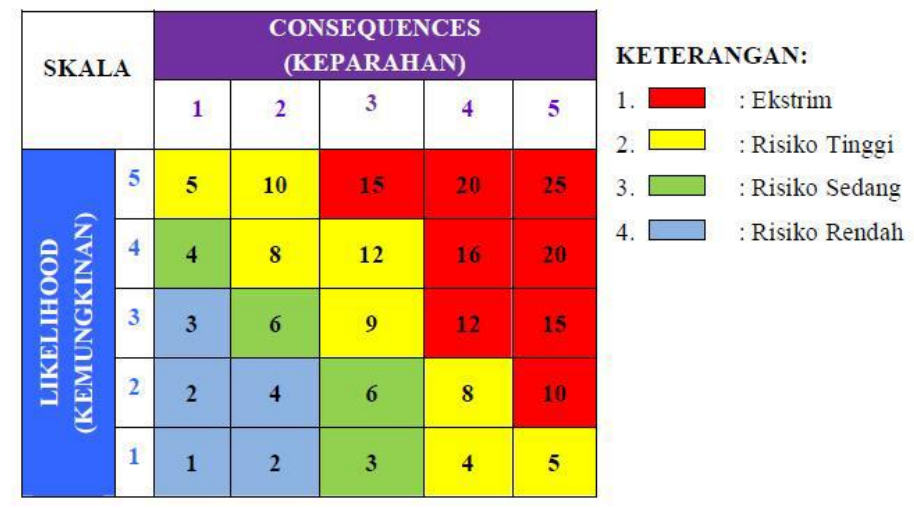

Gambar 1. Risk Matrix

(Sumber: http://journals.ums.ac.id/index.php/jiti/article/download/621/361)

Dari risk matrix di atas kemudian dapat dihitung skor resiko dan prioritas untuk melakukan tindakan perbaikan. Untuk menghitung skor resiko adalah sebagai berikut:

Skor resiko $=$ likelihood $x$ consequences ... (1)

Contoh perhitungan pada skor resiko pertama diketahui nilai likelihood sebesar 4 dan nilai consequences sebesar 2 , maka perhitungan adalah sebagai berikut:

Skor resiko $=4 \times 2=8$ 


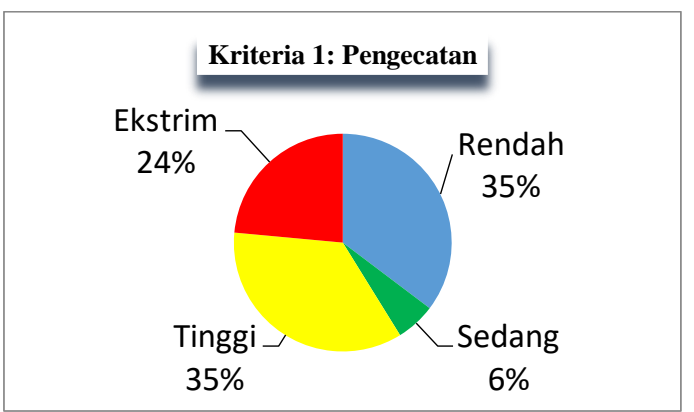

Gambar 2. Hasil kuesioner pengecatan oleh crew kapal (Sumber: Hasil perangkingan oleh penulis)

Resiko bahaya yang ditimbulkan pada saat crew melaksanakan pekerjaan pengecatan antara lain: Pertama resiko ekstrim, pada area pengecatan dimana terdapat kelalaian pada saat melaksanakan kerja yang bisa membahayakan para pekerja. Kedua resiko tinggi, yaitu pada beberapa area kerja dengan uraian resiko sebagai berikut: Abk bisa terjatuh dari ketinggian jika mengecat tidak memakai safety body harness dan cat masuk kemata jika tidak memakai safety googles. Ketiga resiko sedang, yaitu Abk terpeleset pada saat melaksanakan pengecatan jika tidak memakai safety shoes. Keempat resiko rendah, yaitu bisa menyebabkan iritasi pada kulit jika terkena bahan kimia pada saat melakukan pengecatan.

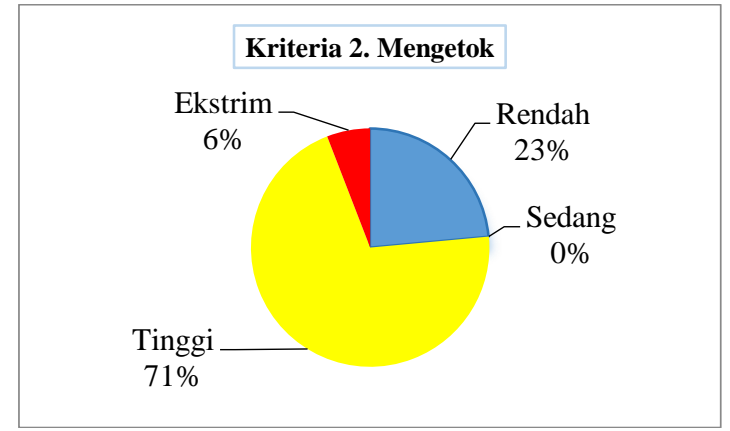

Gambar 3. Hasil Kuesioner Menggetok oleh crew kapal

(Sumber: Hasil perangkingan oleh penulis)

Resiko bahaya yang ditimbulkan pada saat crew melaksanakan pekerjaan mengetok antara lain: Pertama resiko ekstrim yaitu pekerjaan yang dilaksanakan jika tidak berhati hati atau tergesagesa bisa mengakibatkan kecelakaan kerja. Kedua resiko tinggi, pada saat mengetok karat bisa masuk kemata jika pekerja tidak menggunakan safety googles. Ketiga resiko rendah, yaitu pada beberapa area kerja dengan uraian resiko sebagai berikut:Tersandung dengan material yang berserakan jika tidak memakai safety shoes dan mengakibatkan terkena serpihan - serpihan karat yang bisa melukai wajah kepala dan tangan.

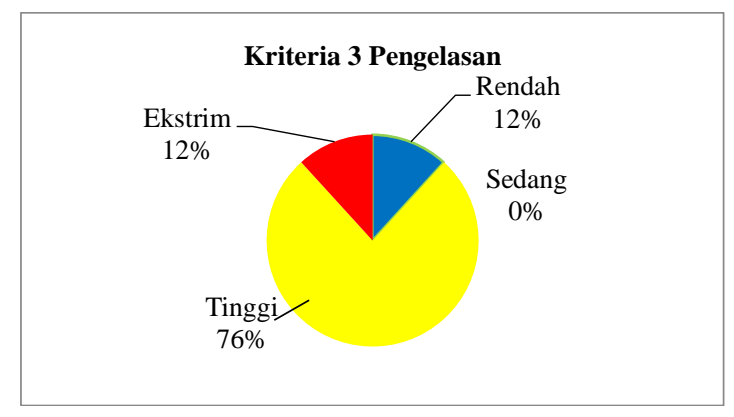


Gambar 4. Hasil kuesioner pengelasan oleh crew kapal (Sumber: Hasil perangkingan oleh penulis)

Resiko bahaya yang ditimbulkan pada saat crew melaksanakan pekerjaan pengelasan antara lain: Pertama resiko ekstrim, yaitu yaitu pekerjaan pengelasan jika bekerja tidak memakai kap las bisa mengakibatkan mata menjadi perih dan kemungkinan besar mengalami kebutaan. Kedua resiko tinggi, yaitu kulit bisa terbakar jika tidak memakai wearpack dan safety gloves. Keempat resiko rendah, yaitu pada saat melaksanakan pengelasan pekerja tidak berhati - hati sehingga terkena serpihan pengelasan.

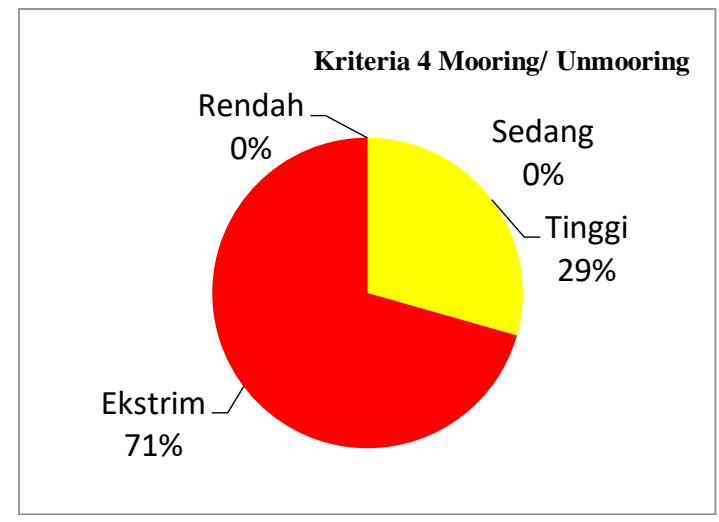

Gambar 5. Hasil kuesioner mooring/ unmooring oleh crew kapal (Sumber: Hasil perangkingan oleh penulis)

Resiko bahaya yang ditimbulkan pada saat crew melaksanakan pekerjaan mooring/ unmooring antara lain: Pertama resiko ekstrim, yaitu penggunaan wire dan tali yang sudah tua dan rusak bisa menyebabkan kecelakaan sehingga dapat mengakibatkan tali dan wire menjadi putus dan dapat mengenai pekerja. Kedua resiko tinggi, yaitu pada saat pekerja mengendalikan tali yang rentan mengakibatkan tali putus dan terpental dapat mengenai pekerja sehingga pekerja mengalami cidera.

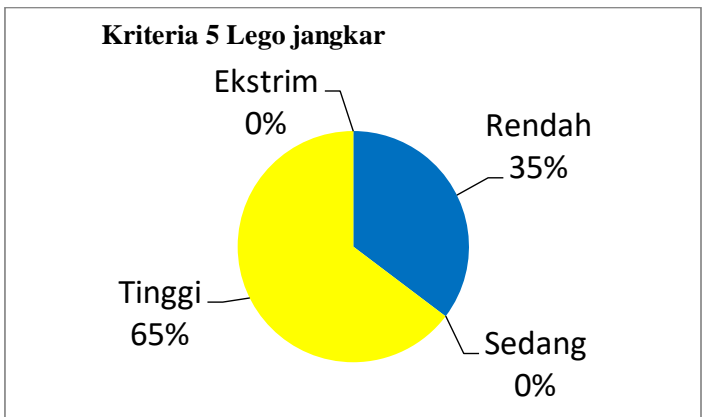

Gambar 4. Hasil kuesioner lego jangkar oleh crew kapal (Sumber: Hasil perangkingan oleh penulis)

Resiko bahaya yang ditimbulkan pada saat crew melaksanakan pekerjaan lego jangkar antara lain: Pertama resiko tinggi, yaitu tidak berhati hati pada saat melaksanakan proses lego jangkar atau kurangnya persiapan dan mengakibatkan tangan terjepit pada saat menurunkan jangkar jika tidak memakai alat keselamatan diri seperti safety gloves. Kedua resiko rendah yaitu 
mata bisa terkena debu dari serpihan - serpihan jangkar pada saat lego jangkar jika tidak memakai buff dan safety googles.

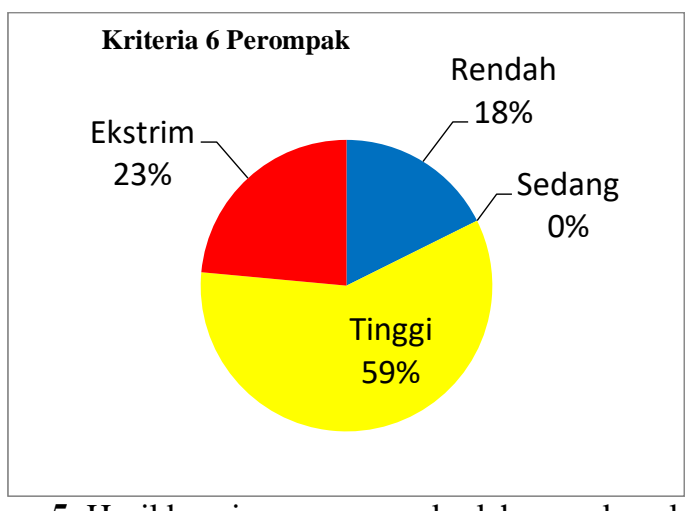

Gambar 5. Hasil kuesioner perompak oleh crew kapal (Sumber: Hasil perangkingan oleh penulis)

Resiko perompak yang ada diatas kapal antara lain: Pertama resiko ekstrim, yaitu perompak bisa membawa barang - barang berbahaya seperti pistol, senjata tajam dll yang dapat membunuh atau melukai para pekerja. Kedua resiko tinggi, yaitu tidak adanya kawat berduri di sekitar kapal dapat menyebabkan perompak bisa naik dengan mudah diatas kapal. Ketiga resiko rendah, yaitu tidak adanya SSO (ship security officer) yang mengakibatkan keamanan yang kurang ketat.

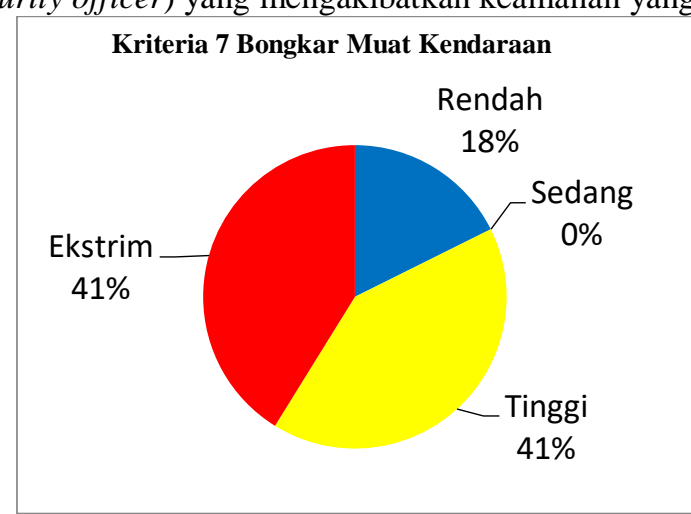

Gambar 6. Hasil kuesioner bongkar muat oleh crew kapal

(Sumber: Hasil perangkingan oleh penulis)

Resiko bahaya yang ditimbulkan pada saat crew melaksanakan pekerjaan bongkar muat kendaraan antara lain: Pertama resiko ekstrim, yaitu Abk pada saat melaksanakan bongkar muat kendaraan tidak berhati - hati dapat menyebabkan kegencet mobil/truk yang ada dikapal yang bisa mengangkut nyawa seseorang. Kedua resiko tinggi, yaitu pada saat ngelashing kendaraan para pekerja tidak memakai sarung tangan yang dapat membuat tangan pekerja terjepit lashing. Ketiga resiko rendah, yaitu terpeleset pada saat bongkar muat kendaraan dikarenakan pekerja tidak memakai safety shoes. 


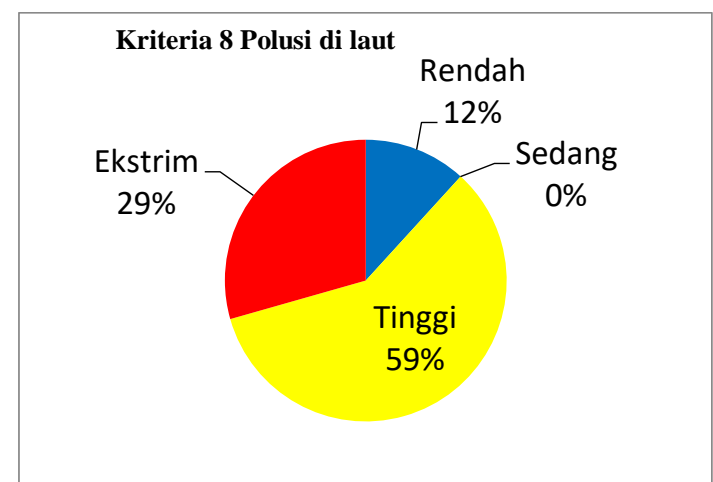

Gambar 7. Hasil kuesioner polusi dilaut oleh crew kapal (Sumber: Hasil perangkingan oleh penulis)

Resiko bahaya yang ditimbulkan adanya polusi dilaut antara lain: Pertama resiko ekstrim, yaitu disebabkan oleh tumpahan minyak. Kedua resiko tinggi, yaitu disebabkan oleh sampah plastic ke laut/ buang limbah dari pabrik. Ketiga resiko rendah, yaitu disebabkan buang limbah got sisa tumpahan minyak dari kapal.

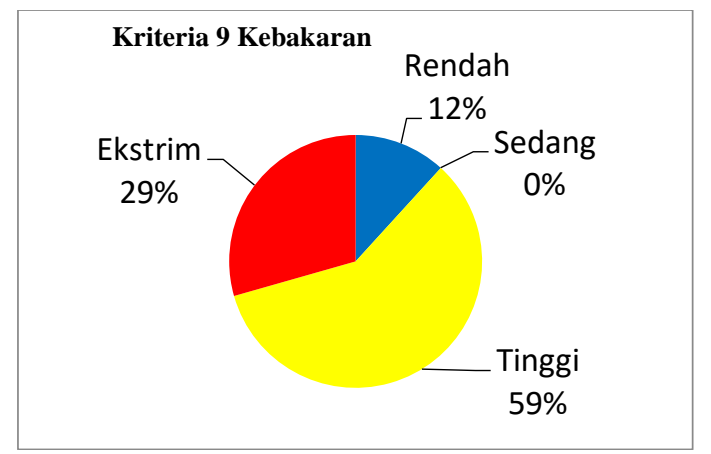

Gambar 8. Hasil kuesioner kebakaran oleh crew kapal

(Sumber: Hasil perangkingan oleh penulis)

Resiko bahaya yang ditimbulkan pada saat terjadinya kebakaran antara lain: Pertama resiko ekstrim, yaitu bisa mengakibatkan kematian pada saat kebakaran terjadi. Kedua resiko tinggi, yaitu pada saat terjadinya kebakaran Abk tidak memakai respirator (alat untuk bernafas) yang membuat Abk kehabisan nafas saat kebakaran tersebut. Ketiga resiko rendah, yaitu dapat menyebabkan luka ringan pada crew kapal yang terkena benda yang mudah terbakar

Tabel 3. Klasifikasi resiko kegiatan diatas kapal

\begin{tabular}{|c|c|c|c|c|}
\hline No & Uraian Temuan Resiko & Diterima & Diabaikan & Dikendalikan \\
\hline 1 & $\begin{array}{l}\text { Abk bisa terjatuh dari ketinggian } \\
\text { jika mengecat tidak memakai } \\
\text { safety body harness }\end{array}$ & & & $\sqrt{ }$ \\
\hline 2 & $\begin{array}{l}\text { Cat masuk kemata jika tidak } \\
\text { memakai safety googles }\end{array}$ & $\sqrt{ }$ & & \\
\hline 3 & $\begin{array}{l}\text { Abk terpeleset pada saat } \\
\text { melaksanakan pengecatan }\end{array}$ & & $\sqrt{ }$ & \\
\hline 4 & $\begin{array}{l}\text { Pada saat pekerja mengendalikan } \\
\text { tali yang rentan, mengakibatkan } \\
\text { tali putus dan terpental sehingga } \\
\text { dapat mengenai pekerja }\end{array}$ & & & $\sqrt{ }$ \\
\hline 5 & Pada saat ngelashing kendaraan & $\sqrt{ }$ & & \\
\hline
\end{tabular}




\begin{tabular}{|l|l|c|c|c|}
\hline & $\begin{array}{l}\text { para pekerja tidak memakai safety } \\
\text { gloves }\end{array}$ & & & \\
\hline 6 & $\begin{array}{l}\text { Membuang sampah plastic dan } \\
\text { minyak kelaut }\end{array}$ & & $\sqrt{ }$ \\
\hline 7 & Tidak memakai safety shoes & $\sqrt{ }$ & & \\
\hline
\end{tabular}

(Sumber: Hasil perangkingan oleh penulis)

Tabel diatas dijelaskan bahwa klasifikasi resiko dibagi menjadi 3 bagian yaitu: Pertama, diterima yang artinya bisa dievaluasi kedepannya. Kedua, diabaikan yang artinya kejadiannya tidak fatal jadi bisa diabaikan. Ketiga, dikendalikan yang artinya fatal harus dievaluasi atau diperbaiki kedepannya.

Tabel 4. Resiko bahaya berdasarkan hasil kuesioner

\begin{tabular}{|l|l|c|c|}
\hline No & \multicolumn{1}{|c|}{ Resiko bahaya } & Ekstrim & Rangking \\
\hline 1. & Pengecatan & $24 \%$ & 5 \\
\hline 2. & Mengetok & $6 \%$ & 8 \\
\hline 3. & Pengelasan & $12 \%$ & 7 \\
\hline 4. & Mooring/Unmooring & $71 \%$ & 1 \\
\hline 5. & Lego jangkar & 0 & 9 \\
\hline 6. & Perompak & $23 \%$ & 6 \\
\hline 7. & Bongkar muat kendaraan & $41 \%$ & 2 \\
\hline 8. & Polusi dilaut & $29 \%$ & 3 \\
\hline 9. & Kebakaran & $29 \%$ & 4 \\
\hline
\end{tabular}

(Sumber: Hasil perangkingan oleh penulis)

Hasil dari observasi yang dilakukan penulis pada identifikasi resiko kegiatan diatas kapal dengan menggunakan metode Hazard \& Operability Study (HAZOPS), teridentifikasi beberapa potensi bahaya pada semua tahapan di semua potensi bahaya kemudian dianalisis dengan menggunakan tabel analisis resiko, setelah itu merekomendasikan pengendalian resiko.

Berdasarkan hasil perangkingan resiko diketahui kecelakaan yang sering terjadi pada saat melakukan pekerjaan yaitu mayoritas responden menjawab dengan kategori sangat serius (ekstrim) atau rangking 1 yaitu sebanyak $71 \%$ memilih pada pekerjaan Mooring/Unmooring, kedua sebanyak $41 \%$ memilih pada pekerjaan Bongkar Muat Kendaraan, ketiga sebanyak 29\% memilih pada polusi dilaut, keempat sebanyak $29 \%$ memilih pada kebakaran, kelima sebanyak $24 \%$ memilih pada pengecatan, keenam sebanyak $23 \%$ memilih pada perompak, ketujuh sebanyak $12 \%$ memilih pada pengelasan, kedelapan sebanyak $6 \%$ memilih pada mengetok, kesembilan sebanyak $0 \%$ memilih pada lego jangkar.

Penulis menyimpulkan terdapat 2 sumber bahaya yang harus segera diperbaiki yaitu kesadaran awak kapal dalam penggunaan peralatan pelindung diri dan kewaspadaan saat bekerja. Kedua sumber bahaya tersebut merupakan faktor penyebab kecelakaan kerja yang sering terjadi di KMP. Athaya. Ketika ditelusuri penulis, awak kapal yang mengalami kecelakaan kerja tersebut mereka memudahkan suatu pekerjaan dan kurangnya fokus ketika melaksanakan pekerjaan sehari - hari.

Pengendalian resiko atau usulan perbaikan dilakukan berdasarkan hazard (potensi bahaya) yang terjadi. Penulis menganalisis dan memberikan rancangan perbaikan untuk semua sumber bahaya yang ada. Ini bertujuan agar semua permasalahan dari sumber bahaya yang ada didapatkan solusinya. Dengan adanya usulan pengendalian resiko yang diberikan nanti 
perusahaan/ kapal dapat mengurangi tingkat kecelakaan dan mencegah adanya kecelakaan yang serupa lagi dengan sebelumnya.

Berikut merupakan cara pengendalian supaya resiko kegiatan diatas kapal tidak terjadi yaitu: Pertama, pentingnya peningkatan pengawasan oleh Nahkoda maupun Chief Officer terhadap seluruh kegiatan operasional di KMP. Athaya. Kedua, ABK dalam melaksanakan pekerjaan wajib focus dan konsentrasi dalam berkerja untuk menghindari resiko kecelakaan.. Ketiga, Anak buah kapal yang tidak menggunakan peralatan pelindung diri harus diberi sanksi. Keempat, ABK diharapkan dapat saling mengingatkan dengan rekan kerja lainnya saling memberikan motivasi agar selalu menggunakan peralatan pelindung diri secara lengkap dan sesuai prosedur pada saat bekerja. Kelima ABK wajib menguasai tugas dan tanggung jawab serta komitmen dalam melaksanakannya. Keenam, kedisiplinan ABK dalam menerapkan prosedur keselamatan.

\section{Kesimpulan}

Berdasarkan rumusan masalah dan hasil analysis serta pembahasan dapat disimpulkan bahwa pemetaan identifikasi resiko kegiatan diatas kapal dengan menggunakan metode Hazop Analysis didapatkan Bahaya yang paling dominan yaitu resiko (Ekstrim) yang teridentifikasi dari 9 sumber hazards (pengecatan, mengetok, pengelasan, mooring/ unmooring, lego jangkar, perompak, bongkar muat kendaraan, polusi dilaut, kebakaran). Pekerjaan yang dapat menyebabkan kecelakaan paling dominan atau sering terjadi yaitu pada pekerjaan Mooring/ Unmooring persentase $71 \%$.

Berdasarkan penelitian yang telah dilakukan di KMP. Athaya maka saran yang dapat diberikan oleh penulis adalah Pertama, untuk pihak kapal terutama Nahkoda agar memberikan pemahaman kesadaran akan bahaya terhadap pekerjaan jika tidak memakai alat keselamatan. Kedua, sebelum melaksanakan kerja, lakukan briefing/safety meeting terlebih dahulu oleh Nahkoda maupun Chief Officer. Ketiga, Saling mengingatkan antara anak buah kapal tentang penggunaan peralatan pelindung diri. Keempat, Fokus dalam bekerja. Kelima, waspada dan berhati-hati saat bekerja di tempat yang berbahaya. Keenam, pastikan bahwa semua peralatan pelindung diri dilakukan perawatan dan siap untuk digunakan. Kedelapan penerapan Standart Operational Prosedur (SOP) dan intruksi kerja yang berlaku diatas Kapal.

\section{Ucapan Terima Kasih}

Penulis mengucapkan terimakasih kepada dosen pembimbing yang telah membimbing dalam penelitian ini dan penulis juga mengucapkan terima kasih kepada seluruh Civitas Akademika Politeknik Pelayaran Surabaya yang telah mengijinkan dalam pembuatan penelitian ini.

\section{Daftar Pustaka}

Hendro Nurcahyono (2013), Definisi Hazard and Operability Studies (HAZOP). Referensi: https://hendronurcahyo.wordpress.com/2013/12/16/hazop-hazard-and-operabilitystudies-dalam-k3/. (16 December 2013).

Simanjuntak (1994). Definisi Keselamatan dan Kesehatan Kerja. Universitas Diponegoro. Referensi: http://eprints.undip.ac.id/61113/3/BAB_III.pdf.

Restu Putri, D. P., Sari,Resti Prima Dyan. (2015, juni 01). Analisis Kecelakan Kerja Dengan Menggunakan Metode Hazard and Operability Study. Referensi: http://journals.ums.ac.id/index.php/jiti/article/download/621/361. 
, International Management Code for the Safe Operations of Ships and for Pollution Prevention (ISM Code)' 2015 Edition - Amandment 2, December 20178.3 Regulation 10.

Prosedur Keselamatan \& Kesehatan Kerja' Tahun 2010. Nomor JL-100-10. Diakses pada tanggal 18 september 2020. 